\title{
Peran Kepolisian Dalam Menangani Kasus Tradisi Penerbangan Balon Udara di Ponorogo
}

\author{
Ferdin Okta Wardana ${ }^{1)}$, Zaid ${ }^{2}$ \\ ${ }^{1}$ Magister Hukum, Universitas Muhammadiyah Yogyakarta, D.I. Yogyakarta, Indonesia \\ ${ }^{2}$ Magister Hukum, Universitas Muhammadiyah Yogyakarta, D.I. Yogyakarta, Indonesia \\ Correspondence email: foktawardana@gmail.com; zaidrusdianto@gmail.com
}

\begin{abstract}
Abstrak. Penelitian ini bertujuan untuk untuk mengungkapkan bagaimana peran kepolisian dalam menangangi kasus tradisi penerbangan balon udara di Ponorogo yang meliputi penegakan hukum, hambatan yang dialami, serta konsep kedepannya berdasarkan sudut pandang dari kepolisian. Karenanya, penelitian ini akan bersifat yuridis empiris dengan menggunakan pendekatan perundang-undangan dan kualitatif. Setelah melakukan pengolahan data menggunakan analisis deskriptif, hasil penelitian ini mengungkapkan bahwa pihak kepolisian memiliki wewenang untuk melakukan penegakan hukum terhadap siapa saja yang melanggar ketertiba, keselamatan ataupun peraturan perundang-undanga. Hanya saja dalam masalah penyidikan, kepolisian menyerahkan wewenang tersebut kepada Pegawai Penyidik Negeri Sipil (PPNS) dalam bidang penerbangan. Selain itu, pihak kepolisian masinh-masing sektor di Kabupaten Ponorogo juga memiliki kesulitan ataupun hambatan yang mayoritasnya adalah menjadikan tradisi dan kurangnya pengetahuan dari masyarakat serta kurangnya peran pemerintah daerah sebagai faktor utama. Karenanyam pihak kepolisianpun dalam hal ini tidak berharapa bahwa tradisi ini harus dihilangkan, hanya saja kedepannya harus ada pengawasan dan kontrol yang ketat sehingga praktek terhadap tradisi penerbangan balon udara ini tidak membahayakan keselamatan dan keamanan siapapun serta tidak melanggar hukum yang berlaku.
\end{abstract}

Keyword: Kepolisian, Tradisi, Balon Udara, Ponorogo

\begin{abstract}
This study aims to reveal how the role of the police in handling the case of the traditional hot air balloon flight in Ponorogo which includes law enforcement, obstacles experienced, and future concepts based on the perspective of the police. Therefore, this research will be juridical and empirical by using a statutory and qualitative approach. After processing data using qualitative analysis, the results of this study reveal that the police have the authority to enforce the law against anyone who violates the order, safety, or laws and regulations. It's just that in matters of investigation, the police hand over the authority to the Civil Investigating Officer (PPNS) in the field of aviation. In addition, the police in each sector in Ponorogo Regency also have difficulties or obstacles, the majority of which are making tradition and lack of knowledge from the community and the lack of the role of local government as the main factors. Therefore, even the police, in this case, do not expect that this tradition should be eliminated, it's just that in the future there must be strict supervision and control so that the practice of this hot air balloon flight tradition does not endanger the safety and security of anyone and does not violate applicable laws.
\end{abstract}

Keywords: Police, Tradition, Air Balloons, Ponorogo

\section{PENDAHULUAN}

Indonesia adalah negara dengan cita-cita supremasi hukum, yang berarti bahwa individu dan otoritas harus mengikuti hukum dan bertindak sesuai hukum. Ini adalah cita-cita yang berada di atas politik, karena kita semua tunduk pada hukum ${ }^{1}$. Namun di sisi lain, Indonesia juga merupakan negara yang memiliki banyak keanekaragaman suku, bahasa, biuda hingga tradisi yang kemudian menajdikan identitas suku setiap daerah masing-masing ${ }^{2}$. Sayangnya, cita-cita untuk membangun supremasi hukum akan dihadapkan dengan masalah dimana ketika suatu tradisi dalam suatu daerah berpotensi dapat melanggar hukum. misalnya tradisi menerbangkan balon udara yang ada di daerah jawa tengah dan jawa timur yang disinyalir sudah dilakukan jauh sebelum sebelum Indonesia dijajah. Tradisi ini sendiri di Ponorogo sering disebut sebagai "umbulan" atau "ombolan" sudah turun menurun dilakukan hingga menjadi tradisi sejak dahulu kala oleh masyarakat Buddha ketika itu ${ }^{3}$. Namun saat ini, Kegiatan tradisi penerbangan balon udara ini dilakukan oleh masyarakat kabupaten Ponorogo pada setiap hari raya Idul Fitri khsusunya hari raya ke 7 (tujuh) seagai bentuk penghormatan dari batoro katong selaku pendakwah pada masa itu kepada Ki Ageng Kutu Surya Alam dengan tujuan untuk mengurangi gejolak yang sedang terjadi atas gugurnya pemimpinya ketika itu.

${ }^{1}$ Ruth Gavison, “Culture, society, law and adjudication”, International Journal of Constitutional Law, Volume 11, Issue 4, (Oktober, 2013): 1114.

${ }^{2}$ Ratnasari Dwi Pratiwi, "Pengawasan Penerbangan Balon Udara Pada Kegiatan Budaya Masyarakat Berdasarkan Pasal 11 Peraturan Menteri Perhubungan Nomor 40 Tahun 2018 Tentang Penggunaan Balon Udara Pada Kegiatan Budaya Masyarakat,” Jurnal Ilmu Hukum 6 No.3, no. N 2442-4641 (Juli, 2019): 50.

${ }^{3}$ Kaled Hasby Ashshidiqy, "Mengulik Sejarah Tradisi Balon Udara Di Ponorogo, Apa Benar Sudah Ada Sejak Abad Ke7?,” Madiunpos.com, (27 mei 2020) 
Hanya saja, penerbagan balon udara ini akan bermasalah ketika tidak ada kontrol dan pengawasan. Karena hal ini dapat menggangu jalur udara penerbangan bagi pesawat. Karenanya, Pemerintah melalui Mentri Perhubungan telah mengeluarkan Peraturan Menteri Perhubungan (PERMENHUB) Nomor 40 Tahun 2018 tentang Penggunaan Balon Udara Sebagai Budaya Masyarakat. Dan dalam Pasal 1 angka 48 Undang-Undang No 1 Tahun 2009 tentang Penerbangan yang menjelaskan bahwa wajibnya menjaga keamanan wilayah udara dengan menciptakan keadaan terpenuhinya keselamatan dalam pemanfaatan wilayah udara, pesawat udara, bandaa udara, angkutan udara dan lain sebagainya. Dan di antara bahaya yang ditimbulkan dari balon udara selain menyebabkan kecelakaan pesawat, menyebabkan konsleting, kebakaran hutam dan kerukana pemukiman warga juga diungkapkan dalam penelitian sebelumnya ${ }^{4}$. Karenanya tradisi penerbangan balon udara ini memiliki dampak distruktif yang membahayakan yang sebenarnya harus segera di atasi oleh hukum maupun penegaknya.

Ketika penelitian terdahulu hanya sebatas pembahasan terkait pengawasan semata ${ }^{5}$, maka penelitian ini akan berusaha mengkaji peran penegak hukum dalam hal ini kepolisian dalam menangangi kasus penerbangan balon udara yang dapat membahayakan. Dan ketika penelitian sebelumnya yang lain hanya berfokus pada wilayah daerah Wonosobo $^{6}$, maka penelitian ini akan berfokus pada tradisi yang terjadi di daerah Ponorogo. Dengan demikian maka tujuan penelitian ini adalah untuk mengungkapkan bagaimana peran kepolisian dalam menangangi kasus tradisi penerbangan balon udara di Ponorogo yang meliputi penegakan hukum, hambatan yang dialami, serta konsep kedepannya berdasarkan sudut pandang dari kepolisian.

\section{METODE}

Mengingat bahwa tujuan dari penelitian ini adalah untuk engetahui peran kepolisian, maka tentu penelitian ini bukan hanya bersifat yuridis normatif, melainkan juga empiris. Sehingga selain pendekatan perundang-undangan, pendekatan kualitatif juga diimplementasikan dalam penelitian ini. Bukan hanya itu, penelitian ini juga mengambil sumber data sekunder melalui tinjauan pustaka maupun primer yang diperoleh langsung dari sumber pertama melalui bahan-bahan hukum primer yang bersifat otoritatif dan sekunder sebagai penjelas dari bahan hukum primer baik dari buku, jurnal ataupun pendapat ahli. Teknik pengumpulan data yang diaplikasikan dalam penelitian ini berupa teknik studi pustaka dan juga wawancara langusng kepada narasumber ataupun informan. Pihak yan gmenjadi narasumber sekaligus Informan dalam penelitian ini melibatkan tiga orang di antaranya adalah;

1. IPTU Tutut Ariyanto selaku Kepala Unit Telkom Kepolisian Sektor Sumoroto, Kabupaten Ponorogo

2. AIPTU Tarmuji Selaku Kepala Sentra Pelayanan Kepolisian Terpadu Kepolisian Setktor Sambit, Kabupaten Ponorogo

3. AIPTU Akhmad Taufik Hidayat SH selaku kepala BINMAS Kepolisian Sektor Mlarak, Kabupaten Ponorogo

Ketiga Informan di atas mewakili sektornya masing-masing yang diwawancarai langsung oleh peneliti. Setelah mendapatkan data yang cukup. Kemudian data-data yang sudah didapatkan diolah dan dianalisis menggunakan metode analisis deskriptif. Analisis deskriptif ini merupakan analisis yang menjadi ciri khas dari penelitian empiris yang berfungsi untuk memaparkan atas subjek dan objek penelitian tanpa harus melakukan justifikasi terhadap hasil penelitian ${ }^{7}$.

\section{HASIL DAN PEMBAHASAN}

\section{Peran Penegakan Hukum Dari Kepolisian Dalam Menangani Kasus Balon Udara Di Kabupaten Ponorogo}

Terkait upaya penegakan hukum, Prof Ahmad Sudiro berpendapat bahwa bahwa pihak terkait yang memiliki wewenang dalam kasus balon udara salah satunya adalah aparat (kepolisian) setempat. Karenanya Dalam hal ini peneliti melakukan sebuah wawancara kepada IPTU Tutut Ariyanto Kepala Unit Telkom kepolisian Sektor Sumoroto pada tanggal 11 Juni 2021, kepada AIPTU Tarmuji 13 Juni 2021 dan AIPTU Akhmad Taufik Hidayat SH pada tanggal 14 Juni 2021. Dalam kegiatan wawancara tersebut hasil yang di peroleh peneliti antara lain:

${ }^{4}$ Ahmad Faqihurrohman, “Tanggung Jawab Negara Atas Terganggunya Jalur Penerbangan Menuju Yogyakarta Oleh Balon Udara Guna Menjamin Keselamatan Penerbangan”, Skripsi Ilmu Hukum Program Sarjana Fakultas Hukum. (Jakarta: UNTAR, 2020).

${ }^{5}$ Ratnasari Dwi Pratiwi, "Pengawasan Penerbangan Balon Udara Pada Kegiatan Budaya Masyarakat Berdasarkan Pasal 11 Peraturan Menteri Perhubungan Nomor 40 Tahun 2018 Tentang Penggunaan Balon Udara Pada Kegiatan Budaya Masyarakat" Novum : Jurnal Hukum Vol. 6 No. 3 (Juli 2019)

${ }^{6}$ Yohanes Aldi Sundoro dkk, "Sanksi Hukum Penerbangan Balon Udara Ilegal di Kabupaten Wonosobo", Jurnal Pembangunan Hukum Indonesia, vol. 2, no. 2, (Mei 2020).

${ }^{7}$ Mukti Fajar N.D, dan Yulianto Achmad. "Dualisme Penelitian Hukum Normatif \& Empiris: Cetakan V" (Yogyakarta: Pustaka Pelajar, 2019): 183. 
1. Pada sektor Sumoroto, IPTU Tutut Ariyanto mengatakan bahwa penegakan yang dilakukan oleh pihak kepolisian sektor sumoroto terkait balon udara dengan pertama-tama adalah dengan mencoba melimpahkan penagganan penyidikan kepada Otoritas Jasa Penerangan Kementrian Perhubungan sebagaimana juga yang diamanatkan dalam pasal 339 ayat (1) Undang-Undang Republik Indonesia No.1 tahun 2009 tenntang penerbangan bahwa yang diberikan kewenangan penyidikan adalah Pegawai Penyidik Negeri Sipil (PPNS) dalam bidang penerbangan yang tujuanya untuk melakukan sidik dan lidik yang dilimpahkan ke PPNS pada Direktoral perhubungan udara Kementrian Perhubunhan Republik Indonesia (KEMENHUB RI). Akan tetapi mesikpun kegiatan penegakan hukum yang dilakukan kepolisian terhalang dengan adanya pasal 339 ayat 1 tentang penerbangan, kepolisian tetap menangkap pelaku yag menerbangkan balon udara tanpa awak yang selanjutnya akan diproses serta dilakuakn pemeriksaan sesuai hukum yang berlaku yang kemudian dilimpahkan ke PPNS, Jika balon udara jatuh di pemukiman warga dan menyebabkan kerusakan maka pihak kepolisian akan mencari dari mana asal balon udara tersebut dan jika terbukti (ada oknum yang bersalah secara hukum) maka akan diproses secara hukum yang berlaku. Selain itu, kepolisian sektor sumoroto tidak hanya asal menangkap dan memproses akan tetapi juga melihat apakah ada ada unsur lain yang membahayakan seperti bahan peledak dan lain-lain yang sudah dilarang di dalam Undang-Undang Darurat No.12 tahun 1951 tentang Mengubah "Ordonnantie Tijdelijke Bijzondere Strafbepalingen" (Stbl. 1948 No.17) dan Undang-Undang R.I. Dahulu No. 8 Tahun 1948 yang menyebutkan kewenangan Kepolisian dalam menangani kasus tersebut. Sedangkan untuk petasanya sendiri ditangani oleh penyidik dari Polri khususnya dari pihak kepolisian sektor sumoroto dengan dikenakan Undang-undang darurat No.12 tahun 1951 tentang bahan peledak.

2. Sedangkan AIPTU Tarmuji menyatakan bahwa Penegakan yang dilakukan oleh kepolisian sector sambal dalam menagani kasus balon udara yaitu pertama-tama sebisa mungkin dengan melakukan upaya preventif ( pencegahan) serta menghimbau kepada masyarakat agar tidak menerbangkan balon udara karena membahayakan keselamatan baik keselamatan dalam penerbangan maupun dalam masyarakatnya sendiri akan tetapi jika dalam himbauan tersebut masih ada yang melakukan peenrbangan balon udara maka dalam hal ini pihak kepolisian akan menangkap pelaku dan memproses sesuai dengan peraturan yang berlaku. Selain itu Dalam melakukan Razia balon udara, pihak kepolisian tidak mengetahui secara pasti kapan dilakukan penerbangan balon udara karena tidak adanya laporan dari warga masyarakat. Masyarakatpun memilik waktu yang beragam ketika menerbangkan balon udara. Ada yang melakukannya pada pukul 5 pagi atau bahkan bisa tengah malam sebagai bentuk upaya untuk mengelabui polisi sehingga polisi tidak mengetahui. Selain itu, pada hari raya idul fitri tahun 2021 kemarin pihak kepolisian polres ponorogo telah berhasil mengamankan sekitar 33 balon udara dan 1.180 petasan.

3. Di sisi lain, AIPTU Akhmad Taufik Hidayat SH memberi komentar bahwa penegakan hukum yang dilakukan kepolisian Mlarak dalam hal ini sedikit dilematis. Karena sifat polisi itu hanya sekedar membantu dan sangat sulit untuk bertindak lebih jauh karena terjerat dengan pasal 339 ayat 1 tentang penerbangan yang bilamana membahayakan lalu lintas penerbangan maka dari pihak kepolisian hanya akan melakukan penangkapan dan melakukan pemeriksaan semata, selebihnya kemudian dilimpahkan ke PPNS.

\section{Hambatan Yang Dialami Kepolisian Dalam Menangani Kasus Balon Udara Di Kabupaten Ponorogo}

Terkait hambatan yang dialami kepolisian dalam menangani kasus balon udara di kabupaten ponorogo, berikut adalah hasil yang diperoleh oleh peneliti:

1. Pada sektor Sumoroto, IPTU Tutut Ariyanto mengungkapkan beberapa permasalahan yang menjadi hambatan bagi kepolisian. Di aranya adalah bahwa praktek penerbangan balon udara di Ponorogo khususnya sektor Sumoroti ini sudah dianggap Sebagian besar masyarakat sebagai suatu perayaan tradisi hari besar islam sehingga Ketika hukum itu ditegakan rawan akan timbulnya konflik dari kedua belah pihak. Selain itu, selama ini balon udara sifatnya hanya daerah-daerah tertentu saja yang menerbangkanya sehingga yurispudensi dalam penegakan hukum terkait penerbangan balon udara tanpa awak sangat sulit untuk dilaksanakan dengan mempertimbangkan karakteristik dari berbagai daerah. Bukan hanya itu, kurangnya kepeduliah dari pemerintah daerah dalam menangani kasus balon udara ini juga menjadi daftar tambahan dari pihak kepolisian dari sulit untuk mencegahnya. Karena pihak kepolisian juga tidak memiliki kewenangan (lebih jauh) dalam melakukan penyidikan balon udara sehingga kepolisian hanya melakukan tindakan preventif (pencegahan) saja. Dan terakhir, kurangnya kesadaran dari pemerintah daerah kabupaten ponorogo yang mana tidak ikut serta mensosialisasikan meskipun sudah ada surat himbauannya. Padahal, berdasarkan ketentuan Undangundang Nomor 1 tahun 2009 tentang penerbangan yang diperjelas di dalam pasal 10 ayat (1) yaitu 
"penerbangan dikuasi oleh negara dan pembinaanya yang dilakukan oleh pemerintah" sedangkan yang ada didalam paal 10 ayat (2) yang menejlaskan bahwa "pembinaan penerbangan sebagaimana dimaksud pada ayat (1) meliputi aspek pengaturan, pengedalian dan pengawasan. Dalam hal ini Pemerintah dan juga kepolisian harus bekerja sama untuk menertibkan penerbangan balon udara melalui operasi Razia secara rutin.

2. AIPTU Tarmuji juga mengungkapkan kesulitan atau hambatan yang hampir sama dimana ia mengungkapkan bahwa dalam melakukan penegakan hukum, pihak kepolisian mengalami beberapa hambatan diantaranya tingkat kesadaran masyarakat kabupaten ponorogo masih sangat kurang, meskipun menerbangkan balon udara menajdi sebuah tradisi akan tetapi tradisi tersebut sangat berbahaya karena bisa menyebabkan lalu lintas udara terganggu dan juga dapat menyebabkan kebakaran ataupun kerusakan fasilitas umum.

3. Di sector melarak, AIPTU Akhmad Taufik Hidayat SH juga mengnukapkan hambatan yang tidak jauh berbeda dimana dirinya mengungkapkan bahwa pihak kepolisian mengalami beberapa hambatan diantaranya Sebagian masyarakat kabupaten ponorogo menganggap bahwa tradisi menerbangkan balon udara ini merupakan tradisi sejak dulu sehingga sulit untuk dihilangkan hal tersebut membuat pihak kepolisian kesulitan selain terjerat adanya pasal 339 ayat 1 tetang penerbangan, selain itu mereka dalam melakukan peenrbangan dilakukan secara sembunyi sembunyi seolah mengelabui polisi dan dalam hal ini tingkat kesadaran dari pemerintah kabupaten ponorogo juga kurang sehingga pihak kepolisian kesulitan dalam menangani kasus balon udara tanpa awak tersebut.

\section{Konsep Kedepan Dari Kepolisian Terkait Tradisi Penerbangan Balon Udara Di Kabupaten Ponorogo}

Terkait konsep kedepan dari Kepolisian terkait tradisi Penerbangan Balon Udara di Kabupaten Ponorogo, berikut adalah hasil yang diperoleh oleh peneliti:

1. Terakhir IPTU Tutut Ariyanto mengungkapkan bahwa dirinya menyarankan terkait konsep kedepan agar balon udara itu tetap menjadi tradisi sebagaimana adanya hanya saja harus tetap dipantau dan diberikan edukasi bagi masyarakat agar dalam melakukannya tidak melanggar aturan perundang-undangan. dan memang pengawasan sangatlah penting agar bisa menjadi suatu jaminan agar jangan sampai keadaan menjadi tidak stabil ${ }^{8}$. Pada 3 tahun ini Polres Ponorogo beserta instansi terkait dan Dirjen Pehubungan udara sudah mengadakan event atau lomba balon udara tanpa awak dengan syarat di beri tali untuk mengikat sehingga balon tersebut tidak terbang secara bebas dan masih dapat dikontrol.

2. AIPTU Tarmuji mengungkapkan bahwa untuk mencapai suatu keamanan dan ketentraman, maka pihak kepolisian tidak melarang penerbangan balon udara. Hanya saja dengan catatan balon tersebut di ikat dan tidak di kasih petasan karena membahayakan selain itu ukuran balon sesuai dengan aturan yang telah ditetapkan. Karenanya dirinya berharap agar kedepannya masyarakat tidak melibatkan atau tidak memasukkan apapun yang berbahaya di dalam balon udara tersebrut dan juga agar tetap menjalankan protokol keamanan dan keselamatan dalam melakukan penerbangna balon udara.

3. Dan terakhir, AIPTU Akhmad Taufik Hidayat, SH juga mengunkapkan hal yang sam aagr kedepannya tradisi ini memang tidak harus hilang sama sekali dari masyarakat, hanya saya dirinya berharap agar balon udara yang sudah menjadi tradisi itu tidak diiringi dengan komponen-komponen lain atau perilaku-perilaku tertentu yang melanggar aturan hukum. Selain itu dirinyapun berpedan agar balon udara yang dibuat dan diterbangkan nantinya tidak berukuran sangat besar cukup dengan ukuran yang sedang dan diberi tali untuk mengikat sehingga balon dapat diawasi dan dikontrol dengan baik dan bisa dilihat orang banyak.

\section{SIMPULAN}

Penerbangan balon udara yang dilakukan 7 hari setelah hari raya idul fitri telah menjadi tradisi bagi masyarakat kabupaten Ponorogo. Hanya saja tradisi ini lambat laun dirasa sangat membahayakan. Karenanya pihak Kepolisian dalam hal ini memiliki peran penting dalam menangani kasus seperti ini. Penelitian ini pada akhirnya menyimpulkna bahwa pihak kepolisian memiliki wewenang untuk melakukan penegakan hukum terhadap siapa saja yang melanggar ketertiba, keselamatan ataupun peraturan perundang-undanga. Hanya saja dalam masalah penyidikan, kepolisian menyerahkan wewenang tersebut kepada Pegawai Penyidik Negeri Sipil (PPNS) dalam bidang penerbangan. Selain itu, pihak kepolisian masinh-masing sektor di Kabupaten Ponorogo juga memiliki kesulitan ataupun hambatan yang mayoritasnya adalah menjadikan tradisi dan kurangnya pengetahuan dari masyarakat serta kurangnya peran pemerintah daerah sebagai faktor utama. Karenanyam pihak kepolisianpun dalam hal ini tidak berharapa bahwa tradisi ini harus dihilangkan, hanya saja kedepannya harus ada pengawasan dan kontrol yang ketat sehingga praktek terhadap tradisi penerbangan balon udara ini tidak membahayakan keselamatan dan keamanan siapapun serta tidak melanggar hukum yang berlaku.

\footnotetext{
${ }^{8}$ Diana H. Koentjoro, Hukum Administrasi Negara (Jakarta: Ghalia Indonesia, 2004).
} 


\section{DAFTAR PUSTAKA \\ Buku:}

Diana H. Koentjoro, Hukum Administrasi Negara. Jakarta: Ghalia Indonesia, 2004.

D, Mukti Fajar N, dan Yulianto Achmad. "Dualisme Penelitian Hukum Normatif \& Empiris: Cetakan V". Yogyakarta: Pustaka Pelajar, 2019.

\section{Artikel Jurnal}

Gavison, Ruth. "Culture, society, law and adjudication", International Journal of Constitutional Law, Vol. 11, Iss. 4, (Oktober, 2013)

Pratiwi, Ratnasari Dwi "Pengawasan Penerbangan Balon Udara Pada Kegiatan Budaya Masyarakat Berdasarkan Pasal 11 Peraturan Menteri Perhubungan Nomor 40 Tahun 2018 Tentang Penggunaan Balon Udara Pada Kegiatan Budaya Masyarakat" Novum : Jurnal Hukum Vol. 6 No. 3 (Juli 2019).

Sundoro, Yohanes Aldi. dkk. "Sanksi Hukum Penerbangan Balon Udara Ilegal di Kabupaten Wonosobo", Jurnal Pembangunan Hukum Indonesia, vol. 2, no. 2, (Mei 2020)

\section{Skripsi}

Ahmad Faqihurrohman, "Tanggung Jawab Negara Atas Terganggunya Jalur Penerbangan Menuju Yogyakarta Oleh Balon Udara Guna Menjamin Keselamatan Penerbangan”, Skripsi Ilmu Hukum Program Sarjana Fakultas Hukum, Jakarta: UNTAR, 2020.

\section{Peraturan Perundang-Undangan}

Undang-Undang Darurat No.12 tahun 1951 tentang Mengubah "Ordonnantie Tijdelijke Bijzondere Strafbepalingen" (Stbl. 1948 No.17) dan Undang-Undang R.I. Dahulu No. 8 Tahun 1948

Undang-Undang No 1 Tahun 2009 tentang Penerbangan

Peraturan Menteri Perhubungan (PERMENHUB) Nomor 40 Tahun 2018 tentang Penggunaan Balon Udara Sebagai Budaya Masyarakat

\section{Surat Kabar}

Ashshidiqy, Kaled Hasby. "Mengulik Sejarah Tradisi Balon Udara Di Ponorogo, Apa Benar Sudah Ada Sejak Abad Ke-7?," Madiunpos.com. (27 mei 2020) 